\title{
TO GO OR NOT TO GO: \\ EMIGRATION FROM GERMANY
}

\author{
SILKE UEBELMESSER
}

CESIFO WORKING PAPER NO. 1626

CATEGORY 4: LABOUR MARKETS

DECEMBER 2005

An electronic version of the paper may be downloaded
- from the SSRN website: $\quad$ www.SSRN.com
- from the CESifo website: Www.CESifo-group.de 


\title{
TO GO OR NOT TO GO: EMIGRATION FROM GERMANY
}

\begin{abstract}
This study analyzes the qualitative aspects of emigration from Germany taking account of economic and non-economic reasons. The reported willingness to emigrate from Germany in the German Socio-Economic Panel (GSOEP) is explained for men and women by three groups of variables: individual characteristics, household characteristics, and regional characteristics. It turns out that the educational background and West German residency positively affect the willingness to emigrate, whereas German nationality, age, and the family situation are mostly negatively correlated with it.
\end{abstract}

JEL Code: F22, C20, H55.

Keywords: emigration, intention variable, probit estimation, German Socio Economic Panel (GSOEP).

\author{
Silke Uebelmesser \\ Center for Economic Studies at the \\ University of Munich \\ Schackstr. 4 \\ 80539 Munich \\ Germany \\ uebelmesser@Imu.de
}

I would like to thank Sascha O. Becker, Regina Riphahn, Steinar Strøm, and Claudio Thum for many very helpful comments. 


\section{Introduction}

For John Hicks (1932), there was no doubt about why individuals would migrate. It is "[d]ifferences in net economic advantages, chiefly differences in wages, [which] are the main causes of migration". According to this view economic differences induce migration from disadvantaged countries or regions to places where wages are higher, unemployment is lower, and economic prospects in general are better. But how then can there be any emigration from highwage countries like Germany, given that the German wages are in the range of other industrialised countries and the general economic situation is also comparable?

These observations indicate that not only differences in earnings but also other, non-earningsrelated factors affect the propensity to migrate. In order to gauge the quantitative and qualitative evolution of net migration, it is important to know more about immigration and emigration and about the characteristics and motivations of the migrants. This paper deals with emigration in order to shed some light on factors which induce people to think about leaving their country of residence. Although emigration and immigration are only two different sides of the same coin, the migration literature is mostly about immigration. Various studies have looked into the social and economic integration of immigrants in countries like the United States, Canada, Australia, and Israel benefiting from an exhaustive collection of data. These analyses focus on who immigrates (e.g. Borjas, 1987 and 1994) and on how immigrants coming from different countries of origin and arriving at different points in time adapt to the new environment (e.g. Chiswick, 1978, and Borjas, 1994, for a survey). ${ }^{1}$ Emigration, on the contrary, has not been much examined with the exception of emigration from industrialised countries in the form of return migration (e.g. DaVanzo, 1983, and Dustmann, 1996, for a survey) and emigration from developing countries linked to the brain drain problem (e.g. Hamada, 1996, Stark et al., 1997). The educational level of emigrants is also at the centre of the small literature analyzing emigration by natives from industrialised countries (e.g. Iqbal, 2000, and Becker, Ichino and Peri, 2003). These studies, however, exclude many groups of (potential) emigrants by focusing on highly educated individuals. ${ }^{2}$ Hunt (2000) looks at emigration patterns for a larger sample, but restricts her analysis to migration of East Germans to West Germany.

This paper complements these studies and analyzes emigration from Germany with data from the German Socio-Economic Panel (GSOEP) by using the reported attitude towards emigration. The dataset enables the consideration of detailed information at the individual, household, and regional level which helps to determine the characteristics of those who intend to emigrate relative to those who stay in Germany and the most important reasons for emigration.

\footnotetext{
${ }^{1}$ Examples of empirical analyses can be found in Beggs and Chapman (1988, 1990 and 1991), Chiswick and Miller (1985), Dustmann (1993), Greenwood and McDowell (1991), Mayer and Riphahn (2000), and Schmidt (1997).

${ }^{2}$ See also EEAG (2003) for a discussion of highly skilled and highly talented emigrants from Europe to the United States.
} 
The next section presents some facts about emigration from Germany. In section 3, the data set is described. Section 4 develops the econometric framework and presents the results for the willingness to emigrate. Section 5 concludes.

\section{Emigration from Germany}

Before concentrating on the econometric analysis, we describe the volume of emigration from Germany. Figure 1 shows the number of emigrants by region of destination from 1991-1999. ${ }^{3}$

Figure 1: Total emigration from Germany by region of destination

1a) German emigrants

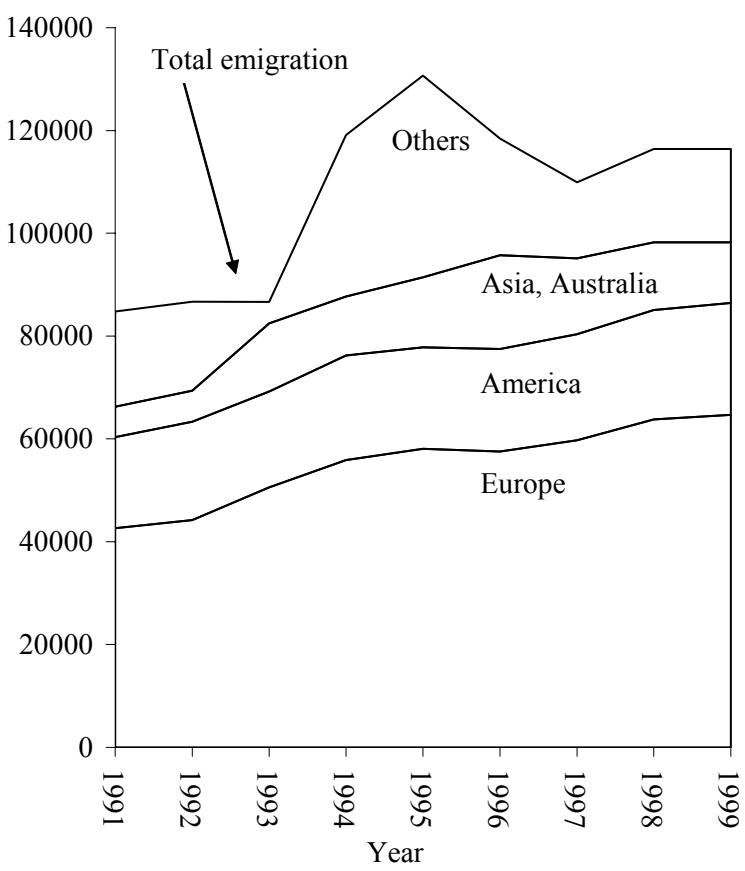

1b) Foreign emigrants

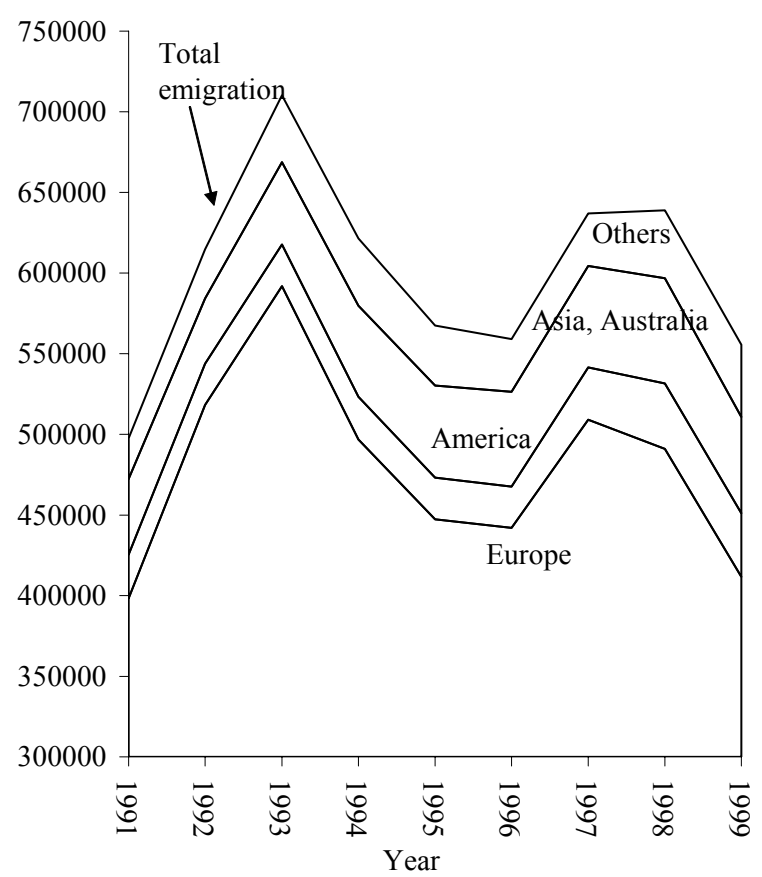

Source: Federal Statistical Office Germany (different volumes).

Up to now, the volume of emigration of Germans from Germany is rather negligible, whereas the number of foreigners who leave Germany to return or to move to another country is much higher. In 1998, e.g., 638,955 foreigners left, but only 116,403 Germans emigrated. Over the period from 1991 to 1999 , less than $0.15 \%$ of the German population left Germany each year according to official data compared to between $7.5 \%$ and $10.5 \%$ of the foreigners. The majority of both groups has chosen another European country as their destination while about $20 \%$ of the Germans and $5 \%$ of the foreigners have moved to the United States and about $10 \%$ of both groups have left Germany for Asia or Australia.

\footnotetext{
${ }^{3}$ As we are interested in emigration on the basis of the rules now in force, i.e. after the establishment of the freedom of movement within the European Union, we focus on emigration in recent years. For an analysis of emigration from and immigration to Germany from 1945-1994, see Münz and Ulrich (1996).
} 
Figure 2 shows a breakdown by age groups for the years 1993, 1996, 1997, and 1998 which we will focus on in the analysis. For all four years, one can observe that the share of individuals who emigrate increases with age up to the age of 25-30 for Germans and up to the age of 18-25 for foreigners in 1993, 1996, and 1997 and up to the age of 25-30 in 1998. The share declines for older individuals. This data gives a first idea of the quantity and quality of emigration from Germany. This will be helpful later when evaluating the plausibility of the data which we will use for the estimations. But note that the number of emigrants is probably underestimated due to problems of registration.

Figure 2: Emigration from Germany 1993, 1996, 1997, 1998
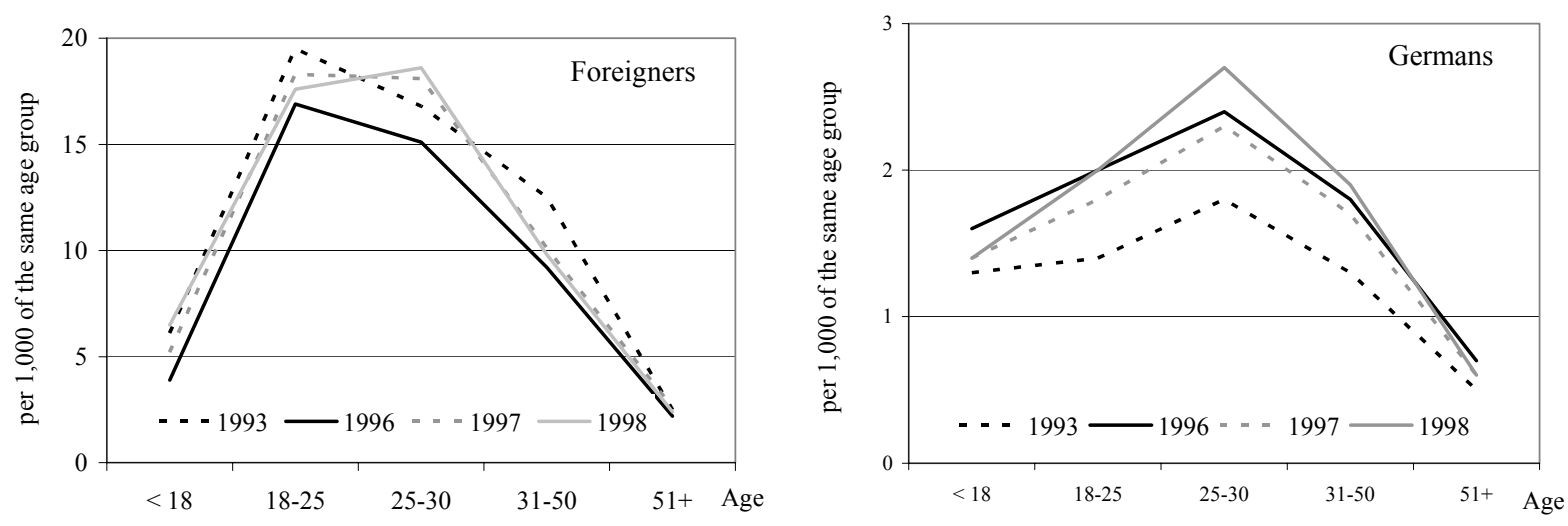

Source: Federal Statistical Office Germany (various volumes)

\section{Data}

The data for this analysis stems from the German Socio-Economic Panel (GSOEP) - samples A, B, C, D, and E. We use the waves 10 (1993), 13 (1996), 14 (1997), and 15 (1998) because these waves are the only ones where individuals are asked about their intentions to emigrate. Wave 13 in addition comprises information about the reasons if the intention to move is positive.

Individuals in the sample are between 16 and 95 years old. As the gender can be expected to influence the propensity to move in different ways - e.g. through stronger family ties for women (Naskoteen and Zimmer, 1980) and through different educational and professional careers - the sample will be subdivided into a female and a male subsample. We excluded individuals with missing values for relevant variables - mostly concerning the propensity to migrate and the schooling and work history. For the four waves considered, the sample consists of 4,354 men and 4,424 women leading to 10,332 male observations and 10,557 female observations due to repeated answers from given individuals in subsequent years. ${ }^{4}$ Table A1 in the appendix describes sample characteristics for the variables used in the empirical analysis.

\footnotetext{
${ }^{4}$ See section 4 for information about how the potential correlations in the error term which arise from repeated answers from given individuals are taken into account.
} 


\section{a) Propensity to emigrate}

We use the answers to the question "Would you consider moving to another country?" of the GSOEP as the dependent variable. Table 1 presents sample statistics for this variable ("move"). Women have a slightly smaller propensity to migrate than men. While $52 \%$ of the men consider migrating "easily" or "if necessary", the share in the female subsample is only $47 \%$.

Table 1: Description of the dependent variable and sample statistics

\begin{tabular}{|lc|cc|cc|}
\hline & & \multicolumn{2}{|c|}{ Women } & \multicolumn{2}{c|}{ Men } \\
\hline \multirow{2}{*}{ move } & \multicolumn{2}{|c|}{ Mean } & SD & Mean & SD \\
\cline { 3 - 6 } & 2.408 & 0.917 & 2.519 & 0.876 \\
\hline \multirow{3}{*}{ no } & Cases & Percent & Cases & Percent \\
\cline { 3 - 6 } rather not & $(1)$ & 1,882 & $17.83 \%$ & 1,344 & $13.01 \%$ \\
yes, if necessary & $(3)$ & 3,766 & $35.67 \%$ & 3,610 & $34.94 \%$ \\
yes, easily & $(4)$ & 3,629 & $34.38 \%$ & 4,048 & $39.18 \%$ \\
\hline Sum & 1,280 & $12.12 \%$ & 1,330 & $12.87 \%$ \\
\hline
\end{tabular}

Source: Waves of 1993, 1996, 1997, and 1998 (GSOEP)

Tables 2 and 3 show the breakdown of the responses for women and men according to a number of personal, household, and regional characteristics. Various patterns are immediately apparent.

For men and women, the propensity to emigrate decreases with age - with few exceptions while it is positively affected by a higher school qualification. A university degree, however, does not further increase the probability compared to a higher secondary school qualification; neither does occupational training compared to an elementary or secondary school qualification. ${ }^{5}$ Employed men and women display a higher propensity to emigrate than unemployed and retired. For the specific occupations considered, we find high probabilities for most of them - including self-employed and civil servants. The probability of thinking about migrating increases with income levels - even though not by much. ${ }^{6}$

Not surprisingly, Germans do not intend to emigrate as much as foreigners who already have special ties to a foreign country. Being single is correlated with a higher propensity to consider emigrating relative to being married to a German while those with a foreign partner display the highest propensity. Children do not play an important role, but the propensity is higher for individuals living in West Germany.

\footnotetext{
${ }^{5}$ In Germany, young individuals with a completed educational - mostly elementary or secondary - school qualification have the opportunity to continue their education after having left school by opting for occupational training which combines vocational on the job training with formal education in vocational schools (Berufsschulen).

${ }^{6}$ For non-retired individuals without any (information about) net wages $-1,761$ out of 9,415 men and 3,358 out of 9,403 women, we simulate net wages using the Heckman procedure (1979). The predicted net wages allow us to judge the "earnings potential" for these individuals in Germany and enable us to analyze any correlation between (potential) earnings in Germany and the propensity to migrate. The estimation results are available from the author.
} 
Table 2: Intention of emigration (Women)

\begin{tabular}{|c|c|c|c|c|c|c|c|c|c|}
\hline \multirow{2}{*}{$\begin{array}{l}\text { Variable } \\
\text { Age }<20\end{array}$} & \multicolumn{2}{|c|}{ Yes, easily } & \multicolumn{2}{|c|}{$\begin{array}{c}\text { Yes, } \\
\text { if necessary }\end{array}$} & \multicolumn{2}{|c|}{ Rather not } & \multicolumn{2}{|c|}{ No } & \multirow{2}{*}{$\begin{array}{r}\begin{array}{l}\text { Total } \\
\text { sample }\end{array} \\
445\end{array}$} \\
\hline & 110 & $24.72 \%$ & 172 & $38.65 \%$ & 118 & $26.52 \%$ & 45 & $10.11 \%$ & \\
\hline Age $20-29$ & 458 & $16.03 \%$ & 1,062 & $37.17 \%$ & 1,017 & $35.60 \%$ & 320 & $11.20 \%$ & 2,857 \\
\hline Age $30-39$ & 359 & $11.76 \%$ & 1,094 & $35.85 \%$ & 1,178 & $38.60 \%$ & 421 & $13.79 \%$ & 3,052 \\
\hline Age $40-49$ & 185 & $9.06 \%$ & 754 & $36.92 \%$ & 799 & $39.13 \%$ & 304 & $14.89 \%$ & 2,042 \\
\hline Age $50-59$ & 128 & $10.36 \%$ & 391 & $31.63 \%$ & 418 & $33.82 \%$ & 299 & $24.19 \%$ & 1,236 \\
\hline Age $60+$ & 40 & $4.32 \%$ & 156 & $16.86 \%$ & 236 & $25.51 \%$ & 493 & $53.30 \%$ & 925 \\
\hline \multicolumn{10}{|l|}{$\begin{array}{l}\text { Education } \\
\text { (highest qualification) }\end{array}$} \\
\hline Elementary & 382 & $10.91 \%$ & 1,002 & $28.61 \%$ & 1,129 & $32.24 \%$ & 989 & $28.24 \%$ & 3,502 \\
\hline Secondary & 493 & $10.77 \%$ & 1,558 & $34.04 \%$ & 1,818 & $39.73 \%$ & 707 & $15.45 \%$ & 4,576 \\
\hline Higher secondary & 238 & $17.84 \%$ & 559 & $41.90 \%$ & 433 & $32.46 \%$ & 104 & $7.80 \%$ & 1,334 \\
\hline University degree & 167 & $14.59 \%$ & 510 & $44.54 \%$ & 386 & $33.71 \%$ & 82 & $7.16 \%$ & 1,145 \\
\hline Occupational training & 757 & $10.35 \%$ & 2,413 & $32.99 \%$ & 2,776 & $37.95 \%$ & 1,368 & $18.70 \%$ & 7,314 \\
\hline \multicolumn{10}{|l|}{ Occupation } \\
\hline Employed & 1,108 & $13.08 \%$ & 3,135 & $37.02 \%$ & 3,127 & $36.92 \%$ & 1,099 & $12.98 \%$ & 8,469 \\
\hline Blue-collar worker & 124 & $12.68 \%$ & 288 & $29.45 \%$ & 365 & $37.32 \%$ & 201 & $20.55 \%$ & 978 \\
\hline Self-employed & 48 & $14.81 \%$ & 139 & $42.90 \%$ & 98 & $30.25 \%$ & 39 & $12.04 \%$ & 324 \\
\hline Trainee & 90 & $18.56 \%$ & 201 & $41.44 \%$ & 146 & $30.10 \%$ & 49 & $9.90 \%$ & 485 \\
\hline White-collar worker & 495 & $12.26 \%$ & 1,490 & $36.92 \%$ & 1,606 & $39.79 \%$ & 445 & $11.03 \%$ & 4,036 \\
\hline Civil servant & 35 & $11.25 \%$ & 139 & $44.69 \%$ & 115 & $36.98 \%$ & 22 & $7.07 \%$ & 311 \\
\hline Other & 316 & $13.53 \%$ & 878 & $37.60 \%$ & 797 & $34.13 \%$ & 344 & $14.73 \%$ & 2,335 \\
\hline Unemployed & 112 & $11.99 \%$ & 259 & $27.73 \%$ & 347 & $37.15 \%$ & 216 & $23.13 \%$ & 934 \\
\hline \multicolumn{10}{|l|}{ Individual Data } \\
\hline German nationality & 1,112 & $11.12 \%$ & 3,403 & $34.02 \%$ & 3,643 & $36.42 \%$ & 1,845 & $18.44 \%$ & 10,003 \\
\hline Other nationality & 168 & $30.32 \%$ & 226 & $40.79 \%$ & 123 & $22.20 \%$ & 37 & $6.68 \%$ & 554 \\
\hline Not married & 685 & $15.97 \%$ & 1,522 & $35.44 \%$ & 1,365 & $31.78 \%$ & 722 & $16.81 \%$ & 4,295 \\
\hline Married & 594 & $9.49 \%$ & 2,107 & $33.65 \%$ & 2,401 & $38.34 \%$ & 1,160 & $18.52 \%$ & 6,262 \\
\hline Foreign partner & 28 & $19.18 \%$ & 74 & $50.68 \%$ & 34 & $23.29 \%$ & 10 & $6.85 \%$ & 146 \\
\hline German partner & 566 & $9.25 \%$ & 2,033 & $33.24 \%$ & 2,367 & $38.70 \%$ & 1,150 & $18.80 \%$ & 6,116 \\
\hline Children under 16 & 509 & $11.02 \%$ & 1,583 & $34.28 \%$ & 1,804 & $39.06 \%$ & 722 & $15.63 \%$ & 4,618 \\
\hline No children under 16 & 771 & $12.98 \%$ & 2,046 & $34.45 \%$ & 1,962 & $33.04 \%$ & 1,160 & $19.53 \%$ & 5,939 \\
\hline West German residence & 1,075 & $14.69 \%$ & 2,780 & $37.98 \%$ & 2,396 & $32.73 \%$ & 1,069 & $14.60 \%$ & 7,320 \\
\hline East German residence & 205 & $6.33 \%$ & 849 & $26.23 \%$ & 1370 & $42.32 \%$ & 813 & $24.12 \%$ & 3,237 \\
\hline \multicolumn{10}{|l|}{ Labour Income } \\
\hline Yes $^{7}$ & 1,220 & $12.97 \%$ & 3,394 & $36.09 \%$ & 3,474 & $36.95 \%$ & 1,315 & $13.98 \%$ & 9,403 \\
\hline Low net income & 303 & $12.69 \%$ & 802 & $33.60 \%$ & 860 & $36.03 \%$ & 422 & $17.68 \%$ & 2,387 \\
\hline Middle net income & 604 & $13.00 \%$ & 1,601 & $34.46 \%$ & 1,756 & $37.80 \%$ & 685 & $14.74 \%$ & 4,646 \\
\hline High net income & 313 & $13.21 \%$ & 991 & $41.81 \%$ & 858 & $36.20 \%$ & 208 & $8.78 \%$ & 2,370 \\
\hline No (retired) & 60 & $5.20 \%$ & 235 & $20.36 \%$ & 292 & $25.30 \%$ & 567 & $49.13 \%$ & 1,154 \\
\hline
\end{tabular}

Source: Waves of 1993, 1996, 1997, and 1998 (GSOEP)

\footnotetext{
${ }^{7}$ Actual or simulated labour income (cf. footnote 6) - with low net income referring to the first quartile of the wage distribution and high net income to the fourth quartile.
} 
Table 3: Intention of emigration (Men)

\begin{tabular}{|c|c|c|c|c|c|c|c|c|c|}
\hline \multirow{2}{*}{$\begin{array}{l}\text { Variable } \\
\text { Age }<20\end{array}$} & \multicolumn{2}{|c|}{ Yes, easily } & \multicolumn{2}{|c|}{$\begin{array}{c}\text { Yes, } \\
\text { if necessary }\end{array}$} & \multicolumn{2}{|c|}{ Rather not } & \multicolumn{2}{|c|}{ No } & \multirow{2}{*}{$\begin{array}{l}\begin{array}{l}\text { Total } \\
\text { sample }\end{array} \\
454\end{array}$} \\
\hline & 81 & $17.84 \%$ & 155 & $34.14 \%$ & 169 & $37.22 \%$ & 49 & $10.79 \%$ & \\
\hline Age 20-29 & 481 & $17.54 \%$ & 1,198 & $43.69 \%$ & 863 & $31.47 \%$ & 200 & $7.29 \%$ & 2,742 \\
\hline Age $30-39$ & 397 & $12.77 \%$ & 1,280 & $41.17 \%$ & 1,098 & $35.32 \%$ & 334 & $10.74 \%$ & 3,109 \\
\hline Age $40-49$ & 180 & $9.24 \%$ & 770 & $39.53 \%$ & 763 & $39.17 \%$ & 235 & $12.06 \%$ & 1,948 \\
\hline Age $50-59$ & 144 & $10.67 \%$ & 477 & $35.36 \%$ & 486 & $36.03 \%$ & 242 & $17.94 \%$ & 1,349 \\
\hline Age $60+$ & 47 & $6.44 \%$ & 168 & $23.01 \%$ & 231 & $31.64 \%$ & 284 & $38.90 \%$ & 730 \\
\hline \multicolumn{10}{|l|}{$\begin{array}{l}\text { Education } \\
\text { (highest qualification) }\end{array}$} \\
\hline Elementary & 466 & $12.56 \%$ & 1,242 & $33.47 \%$ & 1,261 & $33.98 \%$ & 742 & $19.99 \%$ & 3,711 \\
\hline Secondary & 490 & $11.69 \%$ & 1,246 & $37.36 \%$ & 1,304 & $39.10 \%$ & 395 & $11.84 \%$ & 3,335 \\
\hline Higher secol & 236 & $16.92 \%$ & 659 & $47.24 \%$ & 428 & $30.68 \%$ & 72 & $5.16 \%$ & 1,395 \\
\hline University degree & 238 & $12.59 \%$ & 901 & $47.65 \%$ & 617 & $32.63 \%$ & 135 & $7.14 \%$ & 1,891 \\
\hline Occupational ti & 841 & $11.56 \%$ & 2,673 & $36.74 \%$ & 2,694 & $37.03 \%$ & 1,067 & $14.67 \%$ & 7,275 \\
\hline \multicolumn{10}{|l|}{ Occupation } \\
\hline With job & 1,145 & $13.26 \%$ &, 552 & 41. & 3,044 & & 895 & $5 \%$ & 8,636 \\
\hline Blue-collar & 317 & $11.12 \%$ & 986 & $34.60 \%$ & 1,082 & $37.96 \%$ & 465 & $16.32 \%$ & 2,850 \\
\hline Self-e & 108 & $16.69 \%$ & 284 & 43. & 201 & & 54 & & 647 \\
\hline Trainee & 85 & $15.77 \%$ & 208 & 38 & 192 & & 54 & 10. & 539 \\
\hline White-co & 379 & $12.33 \%$ & 1,385 & $45.07 \%$ & 1,098 & 35 & 211 & $7 \%$ & 3,073 \\
\hline Civil se & 84 & $12.35 \%$ & 288 & $42.35 \%$ & 238 & $35.00 \%$ & 70 & $10.29 \%$ & 680 \\
\hline Other & 172 & $21.31 \%$ & 401 & 47. & 233 & 27 & 41 & & 847 \\
\hline Unemployed & 100 & $12.84 \%$ & 263 & $33.76 \%$ & 280 & $35.94 \%$ & 136 & $17.46 \%$ & 779 \\
\hline \multicolumn{10}{|l|}{ Individual Data } \\
\hline German nationali & 1,166 & $12.05 \%$ & 3,759 & 38 & 3,444 & 35 & 1,309 & 13. & 9,678 \\
\hline Other nati & 164 & $25.08 \%$ & 289 & $44.19 \%$ & 166 & 25. & 35 & 5. & 654 \\
\hline Not married & 706 & $16.11 \%$ & 1,860 & $42.44 \%$ & 1,401 & 31 & 416 & $9.49 \%$ & 4,383 \\
\hline Married & 624 & $10.49 \%$ & 2,188 & $36.78 \%$ & 2,209 & $37.13 \%$ & 928 & $15.60 \%$ & 5,949 \\
\hline Foreig1 & 33 & $27.97 \%$ & 54 & $45.76 \%$ & 25 & $21.19 \%$ & 6 & $5.08 \%$ & 118 \\
\hline Germa1 & 591 & $10.14 \%$ & 134 & $36.60 \%$ & 2,184 & $37.45 \%$ & 922 & $15.81 \%$ & 5,831 \\
\hline Children & 493 & $12.04 \%$ & 1,578 & $38.54 \%$ & 1,521 & $37.15 \%$ & 502 & $12.26 \%$ & 4,094 \\
\hline No childre & 837 & $13.42 \%$ & 2,470 & $39.60 \%$ & 2,089 & $33.49 \%$ & 842 & $13.50 \%$ & 6,238 \\
\hline West Ger & 1,094 & $15.23 \%$ & 3,007 & $41.86 \%$ & 2,305 & 32. & 777 & 10. & 7,183 \\
\hline East German residence & 236 & $7.49 \%$ & 1,041 & $33.06 \%$ & 1,305 & $41.44 \%$ & 567 & $18.01 \%$ & 3,149 \\
\hline \multicolumn{10}{|l|}{ Income } \\
\hline Yes $^{8}$ & 1,245 & $13.22 \%$ & 3,815 & $40.52 \%$ & 3,324 & $35.31 \%$ & 1,031 & $10.95 \%$ & 9,415 \\
\hline Low & 293 & $12.31 \%$ & 848 & $35.62 \%$ & 895 & 37.5 & 345 & $14.49 \%$ & 2,381 \\
\hline Middle net incom & 595 & $12.78 \%$ & 1,838 & $39.48 \%$ & 1,699 & $36.50 \%$ & 523 & $11.24 \%$ & 4,655 \\
\hline High net income & 357 & $15.01 \%$ & 1,129 & $47.46 \%$ & 730 & $30.69 \%$ & 163 & $6.85 \%$ & 2,379 \\
\hline No (retired) & 85 & $9.27 \%$ & 233 & $25.41 \%$ & 286 & $31.19 \%$ & 313 & $34.13 \%$ & 917 \\
\hline
\end{tabular}

Source: Waves of 1993, 1996, 1997, and 1998 (GSOEP)

\footnotetext{
${ }^{8}$ Actual or simulated labour income (cf. footnote 6) - with low net income referring to the first quartile of the wage distribution and high net income to the fourth quartile.
} 
As the motivation to emigrate might differ significantly between men and women and for individuals with different characteristics, we complement the description by making use of information available in the 1993 wave of the GSOEP about the potential reasons. Tables 4 and 5 provide an overview of the reasons for migration stated by those who show a positive propensity. ${ }^{9}$

Table 4: Reasons for emigration (Women)

\begin{tabular}{|c|c|c|c|c|c|c|c|c|c|}
\hline \multirow{2}{*}{$\begin{array}{l}\text { Variable } \\
\text { Total }\end{array}$} & \multicolumn{2}{|c|}{$\begin{array}{l}\text { Training / } \\
\text { education }\end{array}$} & \multicolumn{2}{|c|}{ Better job } & \multicolumn{2}{|c|}{ Retirement } & \multicolumn{2}{|c|}{$\begin{array}{l}\text { Family / } \\
\text { friends }\end{array}$} & \multirow{2}{*}{\begin{tabular}{r|} 
Total \\
680 \\
\end{tabular}} \\
\hline & 84 & $12.35 \%$ & 269 & $39.56 \%$ & 180 & $26.47 \%$ & 147 & $21.61 \%$ & \\
\hline Age $<20$ & 18 & $40.91 \%$ & 16 & $36.36 \%$ & 0 & $0 \%$ & 10 & $22.73 \%$ & 44 \\
\hline Age $20-29$ & 60 & $27.65 \%$ & 104 & $47.93 \%$ & 10 & $4.61 \%$ & 43 & $19.82 \%$ & 217 \\
\hline Age $30-39$ & 3 & $1.74 \%$ & 99 & $57.56 \%$ & 26 & $15.12 \%$ & 44 & $25.58 \%$ & 172 \\
\hline Age $40-49$ & 2 & $1.56 \%$ & 41 & $32.03 \%$ & 64 & $50.00 \%$ & 21 & $16.41 \%$ & 128 \\
\hline Age $50-59$ & 1 & $1.18 \%$ & 8 & $9.41 \%$ & 59 & $69.41 \%$ & 17 & $20.00 \%$ & 85 \\
\hline Age $60+$ & 0 & $0 \%$ & 1 & $2.94 \%$ & 21 & $61.76 \%$ & 12 & $35.29 \%$ & 34 \\
\hline \multicolumn{10}{|l|}{ Education } \\
\hline Elementary & 10 & $4.46 \%$ & 74 & $33.04 \%$ & 81 & $36.16 \%$ & 59 & $26.34 \%$ & 224 \\
\hline Secondary & 27 & $10.15 \%$ & 111 & $41.73 \%$ & 69 & $25.94 \%$ & 59 & $22.18 \%$ & 266 \\
\hline Higher secondary & 42 & $37.50 \%$ & 43 & $38.39 \%$ & 10 & $8.93 \%$ & 17 & $15.18 \%$ & 112 \\
\hline University degree & 5 & $6.41 \%$ & 41 & $52.56 \%$ & 20 & $25.64 \%$ & 12 & $15.38 \%$ & 78 \\
\hline Occupational training & 24 & $5.54 \%$ & 182 & $42.03 \%$ & 128 & $29.56 \%$ & 99 & $22.86 \%$ & 433 \\
\hline \multicolumn{10}{|l|}{ Occupation } \\
\hline Employed & 77 & $13.37 \%$ & 231 & $40.10 \%$ & 150 & $26.04 \%$ & 118 & $20.49 \%$ & 576 \\
\hline Unemployed & 5 & $8.77 \%$ & 31 & $54.39 \%$ & 7 & $12.28 \%$ & 14 & $24.56 \%$ & 57 \\
\hline Retired & 2 & $4.26 \%$ & 7 & $14.89 \%$ & 23 & $48.94 \%$ & 15 & $31.91 \%$ & 47 \\
\hline \multicolumn{10}{|l|}{ Individual Data } \\
\hline Not married & 73 & $24.58 \%$ & 120 & $40.40 \%$ & 37 & $12.46 \%$ & 67 & $22.56 \%$ & 297 \\
\hline Married & 11 & $2.87 \%$ & 149 & $38.90 \%$ & 143 & $37.34 \%$ & 80 & $20.89 \%$ & 383 \\
\hline Children under 16 & 23 & $8.52 \%$ & 134 & $49.63 \%$ & 50 & $18.52 \%$ & 63 & $23.33 \%$ & 270 \\
\hline No children under 16 & 61 & $14.88 \%$ & 135 & $32.93 \%$ & 130 & $31.71 \%$ & 84 & $20.49 \%$ & 410 \\
\hline West German residence & 50 & $9.62 \%$ & 198 & $38.08 \%$ & 150 & $28.85 \%$ & 122 & $23.46 \%$ & 520 \\
\hline East German residence & 34 & $21.25 \%$ & 71 & $44.38 \%$ & 30 & $18.75 \%$ & 25 & $15.63 \%$ & 160 \\
\hline
\end{tabular}

Source: Wave 1993 of the GSOEP

Better professional opportunities are important for $60 \%$ of the men and for $40 \%$ of the women. For those individuals, relevant differences in wages and/or employment probabilities seem to exist. However, reasons which are not directly linked to economic differences also play a significant role. $22 \%$ of the men and $26 \%$ of the women want to spend their retirement period abroad. The motivation to migrate is thus not directly related to wage/employment differentials although the economic situation in the destination country is important to judge the purchasing power of the pension benefits. Better institutions for training and education are the reason given by $13 \%$ of

\footnotetext{
${ }^{9}$ For this, we focus on those individuals with a positive propensity to migrate who name "training/education", "better job", "retirement" or "friends/family" as the main reason. Individuals who choose "other reason" (372 women and 321 men) or "no answer" (73 women and 70 men) are excluded.
} 
the men and $12 \%$ of the women. Again, the economic situation only plays an indirect role if these individuals reckon on better job opportunities abroad - or at home - after having completed their studies abroad. ${ }^{10}$ Family reasons are mentioned by men in $4 \%$ of the cases and by women in $21 \%$. Here, the economic situation only indirectly influences the decision to migrate if these individuals follow family members who might have migrated for economic reasons.

Table 5: Reasons for emigration (Men)

\begin{tabular}{|c|c|c|c|c|c|c|c|c|c|}
\hline \multirow{2}{*}{\begin{tabular}{|l|} 
Variable \\
Total \\
\end{tabular}} & \multicolumn{2}{|c|}{$\begin{array}{l}\text { Training / } \\
\text { education }\end{array}$} & \multicolumn{2}{|c|}{ Better job } & \multicolumn{2}{|c|}{ Retirement } & \multicolumn{2}{|c|}{$\begin{array}{c}\text { Family / } \\
\text { friends }\end{array}$} & \multirow{2}{*}{\begin{tabular}{|r|} 
Total \\
879 \\
\end{tabular}} \\
\hline & 116 & $13.20 \%$ & 531 & $60.41 \%$ & 194 & $22.07 \%$ & 38 & $4.32 \%$ & \\
\hline Age $<20$ & 19 & $46.34 \%$ & 18 & $43.90 \%$ & 2 & $4.88 \%$ & 2 & $4.88 \%$ & 41 \\
\hline Age $20-29$ & 80 & $26.14 \%$ & 206 & $67.32 \%$ & 12 & $3.92 \%$ & 8 & $2.61 \%$ & 306 \\
\hline Age $30-39$ & 13 & $5.78 \%$ & 177 & $78.67 \%$ & 27 & $12.00 \%$ & 8 & $3.56 \%$ & 225 \\
\hline Age $40-49$ & 2 & $1.31 \%$ & 92 & $60.13 \%$ & 52 & $33.99 \%$ & 7 & $4.58 \%$ & 153 \\
\hline Age $50-59$ & 2 & $1.72 \%$ & 38 & $32.76 \%$ & 72 & $62.07 \%$ & 4 & $3.45 \%$ & 116 \\
\hline Age $60+$ & 0 & $0 \%$ & 0 & $0 \%$ & 29 & $76.32 \%$ & 9 & $23.68 \%$ & 38 \\
\hline \multicolumn{10}{|l|}{ Education } \\
\hline Elementary & 8 & $2.75 \%$ & 173 & $59.45 \%$ & 93 & $31.96 \%$ & 17 & $5.84 \%$ & 291 \\
\hline Secondary & 41 & $15.07 \%$ & 174 & $63.97 \%$ & 46 & $16.91 \%$ & 11 & $4.04 \%$ & 272 \\
\hline Higher secondary & 53 & $36.81 \%$ & 75 & $52.08 \%$ & 11 & $7.64 \%$ & 5 & $3.47 \%$ & 144 \\
\hline University degree & 14 & $8.14 \%$ & 109 & $63.37 \%$ & 44 & $25.58 \%$ & 5 & $2.91 \%$ & 172 \\
\hline Occupational training & 43 & $7.33 \%$ & 369 & $62.86 \%$ & 144 & $24.53 \%$ & 31 & $5.28 \%$ & 587 \\
\hline \multicolumn{10}{|l|}{ Occupation } \\
\hline Employed & 111 & $14.25 \%$ & 482 & $61.87 \%$ & 161 & $20.67 \%$ & 25 & $3.21 \%$ & 779 \\
\hline Unemployed & 3 & $6.12 \%$ & 41 & $83.67 \%$ & 2 & $4.08 \%$ & 3 & $6.12 \%$ & 49 \\
\hline Retired & 2 & $3.92 \%$ & 8 & $15.69 \%$ & 31 & $60.78 \%$ & 10 & $19.61 \%$ & 51 \\
\hline \multicolumn{10}{|l|}{ Individual Data } \\
\hline Not married & 102 & $24.70 \%$ & 265 & $64.16 \%$ & 30 & $7.26 \%$ & 16 & $3.87 \%$ & 413 \\
\hline Married & 14 & $3.00 \%$ & 266 & $57.08 \%$ & 164 & $35.19 \%$ & 22 & $4.72 \%$ & 466 \\
\hline Children under 16 & 34 & $10.21 \%$ & 228 & $68.47 \%$ & 62 & $18.62 \%$ & 9 & $2.70 \%$ & 333 \\
\hline No children under 16 & 82 & $15.02 \%$ & 303 & $55.49 \%$ & 132 & $24.18 \%$ & 29 & $5.31 \%$ & 546 \\
\hline West German residence & 71 & $11.34 \%$ & 359 & $57.35 \%$ & 170 & $27.16 \%$ & 26 & $4.15 \%$ & 626 \\
\hline East German residence & 45 & $17.79 \%$ & 172 & $67.98 \%$ & 24 & $9.49 \%$ & 12 & $4.74 \%$ & 253 \\
\hline
\end{tabular}

Source: Wave 1993 of the GSOEP

These general patterns can also be found when looking at women and men in more detail. The higher importance of better job opportunities abroad for the migration intention of men compared to women can be observed throughout, independent of individual or household characteristics. Women on the other hand think about migration to a much larger extent because of friends and family members who live abroad whereas this plays a negligible role for men, with the exception of the old and the retired.

\footnotetext{
${ }^{10} \mathrm{We}$ do not have information about the intention of individuals to return after having completed their education. See Dustmann (1995 and 1997) for an analysis of the long-run effects of return migrants.
} 
Thus, the economic situation in the destination country compared to Germany plays a role for the propensity to migrate as can be seen when looking at the importance of "training/education" and "better job" opportunities. But also reasons which are not directly related to economic aspects like spending the retirement period abroad or joining friends and family members are of importance. It is therefore necessary to choose an approach which is flexible enough to allow for different motivations.

\section{b) Intention variable}

Given the few actual emigrants in the GSOEP, and given the fact that in general information about emigration - in contrast to immigration - is hard to find, ${ }^{11}$ the variable on the intention to move allows an approximation of realised migration. As Manski (1990, p. 935) states, "intentions data do potentially convey information about behaviour".

To get a feeling for the reliability of the data set of the GSOEP, we compare it with similar data from the study "Performance of the European Union Labour Market" by the European Commission (1995). In this study, individuals are asked whether they would be willing to work in an EC Member State different from the one of which they are a national. $34 \%$ of the men and $21 \%$ of the women answered the question with yes. With data from the $10^{\text {th }}$ wave (1993) of the GSOEP, we find that $22 \%$ of the men and $11 \%$ of the women name better job opportunities abroad as a possible reason to think about emigrating. ${ }^{12}$ In both data sets, men are more willing to migrate for professional reasons than women. It is not surprising that the numbers from the GSOEP are smaller given the fact that in the GSOEP individuals have to choose the most likely reason among several reasons. ${ }^{13}$ Overall, the answers are comparable.

It is, however, still necessary to reconcile the different orders of magnitude of the statistical information of the Federal Statistical Office Germany and the responses in the GSOEP. From figure 2 and tables 2 and 3 we see that the data from the Federal Statistical Office Germany is quantitatively different but not qualitatively. The absolute number of emigrants is much lower than what one would expect from the answers to the willingness-to-migrate question. But the general picture with an increase in emigration up to the age group 25-30 for Germans and up to 18-25 (25-30 in 1998) for foreigners and a decline thereafter can be found again. ${ }^{14}$

\footnotetext{
11 The U.S. Census Bureau has recently developed some techniques to estimate the number of emigrants, which underlines the difficulty to obtain reliable emigration data. See Bashir and Robinson (1994) for the foreign-born population and Fernandez (1995) for the U.S. born population. In Germany, on the contrary, emigrants are legally obliged to give notice when leaving the country. However, the number of emigrants is probably underreported due to registration problems, and information about the destination country is very limited.

${ }^{12}$ Ratio of those who name "better job opportunities" as the reason to move (tables 4 and 5) to the 2,491 women or 2,440 men respectively in the dataset (wave 13).

${ }^{13} \mathrm{Cf}$. tables 4 and 5 for the other reasons.

${ }^{14}$ This is confirmed by the study of the European Commission (1995). The willingness to work abroad is highest for those below 31 years (39\%) and decreases to $27 \%$ for the $31-49$ year old and to $15 \%$ for the 50 year old and older.
} 
We thus follow Burda et al. (1998) in assuming that intentions are a monotonic function of the variables which motivate migration. We will therefore concentrate on identifying those characteristics which affect the propensity to emigrate. We will interpret the results of the estimation accordingly, namely that individuals with these characteristics will be over-proportionally represented among the emigrants. ${ }^{15}$

\section{Estimation of the propensity to migrate}

According to the standard human capital model, ${ }^{16}$ the mobility decision of an individual is guided by the comparison of the present value of lifetime earnings - labour income and pension benefits - in the home country and in the foreign country, net of migration costs for migration at a certain age. As with all decisions, the individual chooses the alternative that maximises utility. Thus, within this framework, migration occurs when utility with migration exceeds utility without migration. The human capital model suggests comparing the economic situation in the source and in the destination country taking migration costs into account.

However, this modelling has two shortcomings in our context. First, it neglects any reasons which are not earnings-related, but which play an important role when thinking about migration as illustrated in tables 4 and 5. Second, it requires that the destination country with its specific characteristics is known. However, information about the volume of emigration in general and about characteristics of the destination country in particular is mostly lacking.

Our approach alleviates both problems. We assume that the emigration decision is a function of individual characteristics, characteristics of the household, and characteristics of the (home) region. We thus include economic but also non-economic factors which can be important for the (potential) migration decision and aim at identifying their effects. In addition, we abstract from variables concerning the destination countries for the analysis which can be justified as we are only interested in the attitude towards migration and not in the probability of migrating to a specific country. It is reasonable to assume that there is at least one country for individuals with a positive propensity to migrate for which the utility exceeds the utility without migration.

We focus on a systematic analysis of the data. We assume that the decision to emigrate can be approximated by the variables describing the individual characteristics, the characteristics of the household, and the characteristics of the (home) region. ${ }^{17}$ As the dependent variable, we use the reported propensity to move to another country which can be viewed as an ordered response with four categories: (1) “no”, (2) "rather not”, (3) “yes, if necessary” and (4) “yes, easily”.

\footnotetext{
${ }^{15}$ See also Papapanagos and Sanfey (2001) who use intention data to analyze emigration from Albania.

${ }^{16}$ See Sjaastad (1962) for an early version of this model.

${ }^{17}$ Burda et al. (1998) follow a similar approach in analyzing the intention to migrate from East to West Germany.
} 
Table 6: (Modified) marginal effects

\begin{tabular}{|c|c|c|c|c|}
\hline & \multicolumn{2}{|c|}{ Women } & \multicolumn{2}{|c|}{ Men } \\
\hline Variable & $\begin{array}{l}\text { Yes, } \\
\text { easily }\end{array}$ & $\begin{array}{c}\text { Yes, if } \\
\text { necessary }\end{array}$ & $\begin{array}{l}\text { Yes, } \\
\text { easily }\end{array}$ & $\begin{array}{c}\text { Yes, if } \\
\text { necessary }\end{array}$ \\
\hline Baseline probability & 0.100 & 0.355 & 0.114 & 0.404 \\
\hline Age & $\begin{array}{l}-0.079^{*} \\
(0.005)\end{array}$ & $\begin{array}{l}-0.028^{*} \\
(0.006)\end{array}$ & $\begin{array}{l}-0.016 \\
(0.005)\end{array}$ & $\begin{array}{l}-0.005 \\
(0.005)\end{array}$ \\
\hline Education & & & & \\
\hline vs. Elementary & $\begin{array}{l}0.353^{* *} \\
(0.007)\end{array}$ & $\begin{array}{l}0.121 * * \\
(0.008)\end{array}$ & $\begin{array}{l}0.270 * * \\
(0.008)\end{array}$ & $\begin{array}{l}0.076^{* *} \\
(0.008)\end{array}$ \\
\hline Higher secondary vs. Elementary & $\begin{array}{l}0.841^{* *} \\
(0.013)\end{array}$ & $\begin{array}{l}0.208^{* *} \\
(0.008)\end{array}$ & $\begin{array}{l}0.544 * * \\
(0.012)\end{array}$ & $\begin{array}{l}0.124^{* *} \\
(0.007)\end{array}$ \\
\hline University degree vs. Elementary & $\begin{array}{l}1.120^{* *} \\
(0.016)\end{array}$ & $\begin{array}{l}0.243^{* *} \\
(0.007)\end{array}$ & $\begin{array}{l}0.571 * * \\
(0.013)\end{array}$ & $\begin{array}{l}0.133^{* *} \\
(0.008)\end{array}$ \\
\hline Occupational training vs. not & $\begin{array}{l}-0.041 \\
(0.007)\end{array}$ & $\begin{array}{l}-0.014 \\
(0.009)\end{array}$ & $\begin{array}{l}-0.049 \\
(0.008)\end{array}$ & $\begin{array}{l}-0.015 \\
(0.008)\end{array}$ \\
\hline Occupation & & & & \\
\hline Unemployment rate & $\begin{array}{l}-0.013 \\
(0.001)\end{array}$ & $\begin{array}{l}-0.005 \\
(0.002)\end{array}$ & $\begin{array}{l}0.011 \\
(0.002)\end{array}$ & $\begin{array}{l}0.003 \\
(0.002)\end{array}$ \\
\hline Trainee vs. blue-collar worker & $\begin{array}{l}0.176 \\
(0.015)\end{array}$ & $\begin{array}{l}0.056 \\
(0.015)\end{array}$ & $\begin{array}{l}0.087 \\
(0.014)\end{array}$ & $\begin{array}{l}0.025 \\
(0.014)\end{array}$ \\
\hline Other vs. blue-collar worker & $\begin{array}{l}0.153 \\
(0.010)\end{array}$ & $\begin{array}{l}0.052 \\
(0.012)\end{array}$ & $\begin{array}{l}0.410^{* *} \\
(0.014)\end{array}$ & $\begin{array}{l}0.097 * * \\
(0.009)\end{array}$ \\
\hline Self-employed vs. blue-collar worker & $\begin{array}{l}0.435^{* *} \\
(0.020)\end{array}$ & $\begin{array}{l}0.122^{* *} \\
(0.015)\end{array}$ & $\begin{array}{l}0.565^{* *} \\
(0.016)\end{array}$ & $\begin{array}{l}0.121^{* *} \\
(0.008)\end{array}$ \\
\hline Civil servant vs. blue-collar worker & $\begin{array}{l}-0.069 \\
(0.015)\end{array}$ & $\begin{array}{l}-0.025 \\
(0.020)\end{array}$ & $\begin{array}{l}0.114 \\
(0.013)\end{array}$ & $\begin{array}{l}0.032 \\
(0.012)\end{array}$ \\
\hline White-collar vs. blue-collar worker & $\begin{array}{l}0.164^{*} \\
(0.009)\end{array}$ & $\begin{array}{l}0.057^{*} \\
(0.011)\end{array}$ & $\begin{array}{l}0.296^{* *} \\
(0.008)\end{array}$ & $\begin{array}{l}0.082^{* *} \\
(0.007)\end{array}$ \\
\hline Unemployed vs. not & $\begin{array}{l}0.044 \\
(0.011)\end{array}$ & $\begin{array}{l}0.015 \\
(0.013)\end{array}$ & $\begin{array}{l}0.051 \\
(0.010)\end{array}$ & $\begin{array}{l}0.015 \\
(0.010)\end{array}$ \\
\hline Individual Data & & & & \\
\hline Nationality: German vs. Non-German & $\begin{array}{l}-1.013^{* *} \\
(0.019)\end{array}$ & $\begin{array}{l}-0.218^{* *} \\
(0.008)\end{array}$ & $\begin{array}{l}-0.735^{* *} \\
(0.016)\end{array}$ & $\begin{array}{l}-0.142 * * \\
(0.007)\end{array}$ \\
\hline Residence: West German vs. East German & $\begin{array}{l}0.673 * * \\
(0.011)\end{array}$ & $\begin{array}{l}0.275^{* *} \\
(0.017)\end{array}$ & $\begin{array}{l}0.619 * * \\
(0.012)\end{array}$ & $\begin{array}{l}0.219 * * \\
(0.016)\end{array}$ \\
\hline Married to German partner vs. Single & $\begin{array}{l}-0.208^{* *} \\
(0.007)\end{array}$ & $\begin{array}{l}-0.072 * * \\
(0.008)\end{array}$ & $\begin{array}{l}-0.186^{* *} \\
(0.008)\end{array}$ & $\begin{array}{l}-0.055^{* *} \\
(0.008)\end{array}$ \\
\hline Married to foreign partner vs. Single & $\begin{array}{l}0.484 * \\
(0.026)\end{array}$ & $\begin{array}{l}0.131 * * \\
(0.019)\end{array}$ & $\begin{array}{l}0.653 * * \\
(0.036)\end{array}$ & $\begin{array}{l}0.127 * * \\
(0.014)\end{array}$ \\
\hline Children under 3 vs. not & $\begin{array}{l}-0.393 * * \\
(0.006)\end{array}$ & $\begin{array}{l}-0.168^{* *} \\
(0.011)\end{array}$ & $\begin{array}{l}-0.141^{* *} \\
(0.008)\end{array}$ & $\begin{array}{l}-0.046^{*} \\
(0.010)\end{array}$ \\
\hline Children from 4- 6 vs. not & $\begin{array}{l}-0.163 * * \\
(0.007)\end{array}$ & $\begin{array}{l}-0.063^{* *} \\
(0.011)\end{array}$ & $\begin{array}{l}-0.159^{* *} \\
(0.008)\end{array}$ & $\begin{array}{l}-0.053^{* *} \\
(0.010)\end{array}$ \\
\hline Income & & & & \\
\hline $\begin{array}{l}\text { Net hourly wage (in DM) } \\
\text { No (retired) vs. not }\end{array}$ & $\begin{array}{l}0.001 \\
(0.000) \\
-0.424 * * \\
(0.011) \\
\end{array}$ & $\begin{array}{l}0.000 \\
(0.000) \\
-0.185^{* *} \\
(0.021)\end{array}$ & $\begin{array}{l}0.002 * * \\
(0.000) \\
0.261 \\
(0.019) \\
\end{array}$ & $\begin{array}{l}0.000 * * \\
(0.000) \\
0.068 * \\
(0.015) \\
\end{array}$ \\
\hline
\end{tabular}

Note: **, * indicate statistical significance at the $5,10 \%$ level of the simulated effects. Standard errors (in parentheses) are calculated by using the Delta method. $1 \mathrm{DM}=0.51 €$ 
As a statistical model for this categorical data we use an order probit model (maximumlikelihood estimation). Potential correlations in the error terms due to the fact that the sample includes repeated answers from given individuals in subsequent years are taken into account. For this, the repeated observations of given individuals are clustered and the assumption of independence of observations within the different clusters is relaxed while it is still required for observations across clusters.

We first estimate the model. The estimation results for the male and female subsample are given in tables A2 and A3 in the appendix with column 1 presenting results of the basic specification and columns 2 and 3 adding measures of the occupational situation and the environment respectively. We then predict the probabilities for each outcome on the basis of the estimated coefficients for the case that the independent variables are at their sample means. In what follows we will refer to these probabilities as "baseline probabilities".

As the interpretation of the estimated coefficients in an ordered probit model is not straightforward, we proceed as follows. For the marginal effects, we consider marginal variations of the continuous variables and 0-1 variations of the dummy variables focusing on men or women with characteristics according to the sample means. In order to make the marginal impact of a variable on the propensity to migrate comparable across the two subsamples, we modify the marginal effects by dividing them by the baseline probabilities. This gives us the marginal impact of changes in the independent variables on the migration propensity measured in percent of the baseline probabilities. Table 6 presents these (modified) marginal effects ${ }^{18}$ where for easier interpretation, we only display the results for categories 3 ("yes, if necessary") and 4 ("yes, easily"). ${ }^{19}$ The results confirm mostly what one would expect. We only comment on some of them.

The coefficients for the age variables are significant at the 10 percent level in the female subsample and insignificant in the male subsample. With a human capital theory a la Sjaastad (1962) in mind, we would expect the propensity to move to decrease with age as the shorter period abroad decreases the net gains of migration - at least if migration is considered for economic reasons. The very small marginal effects hint at other potential reasons which are not captured by the human capital theory, e.g. joining friends and family members or emigrating in order to spend the years as retiree abroad.

\footnotetext{
${ }^{18}$ The reported effects describe the marginal effects relative to the baseline probability:

(Modified) marginal effect $=\frac{\text { marginal effect }}{\text { baseline probability }}$ for continuous variables (e.g. age)

(Modified) marginal effect $=\frac{\text { dummy set to } 1-\text { dummy set to } 0}{\text { baseline probability }}$ for dummy variables (e.g. nationality)

${ }^{19}$ The results for categories 1 ("no") and 2 ("rather not") are available from the author.
} 
The propensity to migrate should increase with the years of education and training (Borjas, 1996). First of all, highly educated individuals might be more efficient at learning about employment opportunities abroad, thus reducing migration costs. Second, the geographic region which makes up the relevant labour market is larger for highly educated individuals than for less educated individuals. Last but not least, higher education implies better knowledge of foreign languages which is an essential prerequisite for economic and social integration. ${ }^{20}$ The marginal effects show that the significant school and university variables have large effects in the expected direction. With a "Secondary school qualification" the probability for the "yes, easily" alternative increases by $35 \%(27 \%)$ in the female (male) subsample and the alternative "yes, if necessary" increases by $12 \%$ (8\%) for women (men). The effect of a "higher secondary school qualification" and a "university degree" on the propensity to migrate is even larger for both men and women. In general, the marginal effect of a higher educational qualification is more pronounced for women than for men while occupational training does not have any significant effect in either subsample.

The occupation plays a significant role for a "self-employed" and for a "white-collar worker" in the female subsample and for a "self-employed", a "white-collar worker" and "other" forms of occupation in the male subsample relative to an individual who is a "blue-collar worker". Being self-employed is positively correlated with a higher probability to migrate for men and women. It seems therefore that the entrepreneurial spirit of a self-employed outweighs the counterargument brought forward by Naskoteen and Zimmer (1980) that self-employment should lead to a smaller propensity to move as the self-employed are less susceptible to promotion opportunities. "White-collar workers" also display a higher propensity to migrate in both subsamples.

The level of net hourly wages shows a positive and significant effect in the male subsample, but is not significantly different from zero in the female sample. ${ }^{21}$ Retirement, i.e. no wage income, increases the propensity to migrate $(+26 \%$ and $+7 \%$ respectively) for men, but not for women ($42 \%$ and $-19 \%$ respectively).

As to the private environment, the partner variable for those who are married to a German should be negatively correlated with the propensity to move abroad as it is both partners together or the family as a whole who must gain by migrating. ${ }^{22}$ Moving with the partner or the family - especially when there are children - induces higher migration costs as all members of the family incur monetary and non-monetary costs when trying to adapt to a foreign environment. Those with a foreign partner should show a higher propensity to emigrate implying that for those couples the migration costs are lower. We find that with a German partner, women and men display a sig-

\footnotetext{
${ }^{20}$ See, e.g., for the relevance of language skills for social integration Chiswick and Miller (1995) and for economic integration Dustmann (1994).

${ }^{21}$ This does not change in an important way if we estimate the effect for given educational qualifications.

${ }^{22}$ See Mincer (1978) for an analysis of migration decisions of families.
} 
nificantly lower propensity to migrate compared to being single while with a foreign partner, the propensity is higher. Children in the household have a significantly negative effect in both subsamples - though this effect is twice as large for "children under 3" in the female subsample. This underlines that the mobility of women is more affected by family ties.

What is quite surprising at first sight is the significance of living in the western part of Germany in both subsamples and the impact this variable has on the propensity to migrate. Individuals who live in West Germany display a probability for the alternative "yes, easily" ("yes, if necessary") which is $66 \%$ (28\%) higher for women and 60\% (22\%) higher for men than for East Germans. One explanation for this phenomenon could be that more mobile individuals from East Germany have already migrated either to the West or to a foreign country or - to put it differently - that there is a negative selection regarding the mobility of individuals who still live in East Germany. The state unemployment rate, however, has no significant effect.

\section{Conclusions}

In order to shed some light on a so far rather neglected aspect of migration, namely emigration from an industrialised country in particular by natives, this paper determines the characteristics of an individual and his or her environment which positively or negatively influence the propensity to migrate. Especially when discussing the economic consequences of the demographic development, it is important to complement the insights about the projected evolution of lifeexpectancy and fertility with insights about migration in general. This paper aims at providing some indications about the qualitative aspects of emigration - who is most likely to emigrate and for which reasons - from an industrialised country illustrated by the case of Germany.

As the analysis has shown the probable emigrants are young, with an above-average school level and without small children. They are white-collar workers or self-employed. The propensity to emigrate is higher for individuals with a foreign nationality as well as for those residing in West Germany and increases with the wage income. It has also become clear that migration is not exclusively economically motivated. Other reasons like better training or educational opportunities, friends or family abroad or the wish to spend the retirement years in another country also play an important role.

The next step would then be to complement this qualitative study with quantitative analyses provided that the necessary data of actual migration flows is available. Information about the composition and the volume of emigrants could then be combined with the immigration data for better founded projections of net migration flows. This is, however, left for future research. 


\section{Appendix:}

Table A1: Descriptive statistics

\begin{tabular}{|c|c|c|c|c|c|}
\hline & & \multicolumn{2}{|c|}{ Women } & \multicolumn{2}{|c|}{ Men } \\
\hline Variable & Dummy & Mean & SD & Mean & SD \\
\hline Age & & 38.30 & 14.05 & 37.81 & 13.32 \\
\hline $\begin{array}{l}\text { Education (highest qualifica- } \\
\text { tion) }\end{array}$ & & & & & \\
\hline Elementary $^{\circ}$ & $\mathrm{x}$ & 0.33 & 0.47 & 0.36 & 0.48 \\
\hline Secondary & $\mathrm{x}$ & 0.43 & 0.50 & 0.32 & 0.47 \\
\hline Higher secondary & $\mathrm{x}$ & 0.13 & 0.33 & 0.14 & 0.34 \\
\hline University degree & $\mathrm{x}$ & 0.11 & 0.31 & 0.18 & 0.39 \\
\hline Occupational training & $\mathrm{x}$ & 0.69 & 0.46 & 0.70 & 0.46 \\
\hline Occupation & & & & & \\
\hline Blue-collar worker ${ }^{\circ}$ & $\mathrm{x}$ & 0.09 & 0.29 & 0.28 & 0.45 \\
\hline Self-employed & $\mathrm{x}$ & 0.03 & 0.17 & 0.06 & 0.24 \\
\hline Trainee & $\mathrm{x}$ & 0.05 & 0.21 & 0.06 & 0.22 \\
\hline White-collar worker & $\mathrm{x}$ & 0.38 & 0.49 & 0.30 & 0.46 \\
\hline Civil servant & $\mathrm{x}$ & 0.03 & 0.17 & 0.07 & 0.25 \\
\hline Other & $\mathrm{x}$ & 0.22 & 0.42 & 0.08 & 0.28 \\
\hline Unemployed & $\mathrm{x}$ & 0.09 & 0.28 & 0.08 & 0.26 \\
\hline Individual Data & & & & & \\
\hline Nationality: German & $\mathrm{x}$ & 0.95 & 0.22 & 0.94 & 0.24 \\
\hline Residence: West German & $\mathrm{x}$ & 0.69 & 0.46 & 0.70 & 0.46 \\
\hline Married to German partner & $\mathrm{x}$ & 0.58 & 0.49 & 0.56 & 0.50 \\
\hline Married to foreign partner & $\mathrm{x}$ & 0.01 & 0.12 & 0.01 & 0.11 \\
\hline Children $\leq 3$ years & $\mathrm{x}$ & 0.12 & 0.33 & 0.11 & 0.32 \\
\hline Children 4-6 years & $\mathrm{x}$ & 0.08 & 0.27 & 0.07 & 0.26 \\
\hline Income & & & & & \\
\hline Net hourly wages (in DM) & & 49.18 & 51.33 & 73.45 & 50.56 \\
\hline No (retired) & $\mathrm{x}$ & 0.11 & 0.31 & 0.09 & 0.29 \\
\hline Unempl. rate (state level) & & & 12.33 & 4.18 & \\
\hline Number & & 10 , & & 10 , & \\
\hline
\end{tabular}

$\circ$ : Omitted in the estimation to avoid multicollinearity

Source: Waves of 1993, 1996, 1997, 1998 of the GSOEP - except for the unemployment rate which is from Federal Statistical Office Germany (various volumes) 
Table A2: Parameter estimates (Women)

\begin{tabular}{|c|c|c|c|c|c|c|}
\hline Variable & Coeff. & $\begin{array}{l}\text { Std. } \\
\text { Error }\end{array}$ & Coeff. & $\begin{array}{l}\text { Std. } \\
\text { Error }\end{array}$ & Coeff. & $\begin{array}{l}\text { Std. } \\
\text { Error }\end{array}$ \\
\hline Age & -0.066 & $0.025 * *$ & -0.074 & $0.026 * *$ & -0.045 & $0.026^{*}$ \\
\hline $\mathrm{Age}^{2}$ & 0.001 & $0.001 * *$ & 0.002 & $0.001 * *$ & 0.001 & $0.001 *$ \\
\hline $\mathrm{Age}^{3}$ & -0.000 & $0.000 * *$ & -0.000 & $0.000 * *$ & 0.000 & $0.000 * *$ \\
\hline \multicolumn{7}{|l|}{ Education (qualification) } \\
\hline Secondary & 0.181 & $0.038 * *$ & 0.191 & $0.039 * *$ & 0.198 & $0.039 * *$ \\
\hline Higher secondary & 0.410 & $0.050 * *$ & 0.412 & $0.051 * *$ & 0.400 & $0.051 * *$ \\
\hline University degree & 0.498 & $0.056 * *$ & 0.493 & $0.059 * *$ & 0.505 & $0.059 * *$ \\
\hline Occupational training & -0.051 & 0.039 & -0.043 & 0.040 & -0.023 & 0.040 \\
\hline \multicolumn{7}{|l|}{ Occupation } \\
\hline $\begin{array}{l}\text { Unemployment rate } \\
\text { (state level) }\end{array}$ & -0.052 & $0.004 * *$ & -0.006 & 0.008 & -0.007 & 0.008 \\
\hline Unemployed & & & 0.113 & $0.055 * *$ & 0.025 & 0.061 \\
\hline Trainee & & & 0.186 & $0.073 * *$ & 0.095 & 0.076 \\
\hline Other & & & 0.080 & $0.048 *$ & 0.085 & 0.055 \\
\hline Self-employed & & & 0.332 & $0.085 * *$ & 0.218 & $0.088 * *$ \\
\hline Civil servant & & & 0.093 & 0.084 & -0.040 & 0.088 \\
\hline White-collar worker & & & 0.209 & $0.044 * *$ & 0.093 & $0.050 *$ \\
\hline \multicolumn{7}{|l|}{ Individual Data } \\
\hline itizenship & & & -0.465 & $0.069 * *$ & -0.454 & $0.069 * *$ \\
\hline West German residency & & & 0.433 & $0.072 * *$ & 0.425 & $0.072 * *$ \\
\hline Married to foreign partner & & & & & 0.239 & $0.112 * *$ \\
\hline Married to German partner & & & & & -0.117 & $0.037 * *$ \\
\hline Children $\leq 3$ years & & & & & -0.255 & $0.045 * *$ \\
\hline Children 4-6 years & & & & & -0.098 & $0.046 * *$ \\
\hline \multicolumn{7}{|l|}{ Income } \\
\hline Net hourly wage (in DM) & & & & & 0.000 & 0.000 \\
\hline Retired & & & & & -0.279 & $0.086 * *$ \\
\hline$\lambda_{1}:$ threshold for probit & -2.488 & 0.331 & -2.127 & 0.366 & -1.881 & 0.364 \\
\hline$\lambda_{2}:$ threshold for probit & -1.383 & 0.329 & -1.001 & 0.365 & -0.755 & 0.363 \\
\hline$\lambda_{3}:$ threshold for probit & -0.239 & 0.329 & 0.150 & 0.365 & 0.411 & 0.363 \\
\hline Pseudo $\mathrm{R}^{2}$ & 0.052 & & 0.061 & & 0.065 & \\
\hline Log-Likel. & -12984 & 4 & -12874 & 744 & -12803 & 992 \\
\hline
\end{tabular}

Note: Results for the constant and the "year of survey" dummies are not reported. Reference categories are: Elementary school qualification for secondary and higher secondary school qualification, blue-collar worker for trainee, other, selfemployed, civil servant and white-collar worker, and not married for married to a foreign/German partner.

** and * indicate statistical significance at the 5 and 10 percent level respectively for the ordered probit estimation. 
Table A3: Parameter estimates (Men)

\begin{tabular}{|c|c|c|c|c|c|c|}
\hline Variable & Coeff. & $\begin{array}{l}\text { Std. } \\
\text { Error }\end{array}$ & Coeff. & $\begin{array}{l}\text { Std. } \\
\text { Error }\end{array}$ & Coeff. & $\begin{array}{l}\text { Std. } \\
\text { Error }\end{array}$ \\
\hline Age & -0.027 & 0.023 & -0.033 & 0.025 & -0.009 & 0.026 \\
\hline $\mathrm{Age}^{2}$ & 0.001 & 0.001 & 0.001 & 0.001 & 0.000 & 0.001 \\
\hline $\mathrm{Age}^{3}$ & -0.000 & 0.000 & -0.000 & 0.000 & -0.000 & 0.000 \\
\hline \multicolumn{7}{|l|}{ Education (qualification) } \\
\hline Secondary & 0.152 & $0.039 * *$ & 0.161 & $0.039 * *$ & 0.154 & $0.040 * *$ \\
\hline Higher secondary & 0.363 & $0.046 * *$ & 0.311 & $0.049 * *$ & 0.285 & $0.049 * *$ \\
\hline University degree & 0.361 & $0.049 * *$ & 0.335 & $0.052 * *$ & 0.302 & $0.053 * *$ \\
\hline Occupational training & -0.077 & $0.040^{*}$ & -0.034 & 0.041 & -0.029 & 0.041 \\
\hline \multicolumn{7}{|l|}{ Occupation } \\
\hline $\begin{array}{l}\text { Unemployment rate } \\
\text { (state level) }\end{array}$ & -0.040 & $0.004 * *$ & 0.006 & 0.008 & 0.007 & 0.008 \\
\hline Unemployed & & & 0.040 & 0.052 & 0.029 & 0.052 \\
\hline Trainee & & & 0.014 & 0.069 & 0.050 & 0.071 \\
\hline Other & & & 0.258 & $0.058 * *$ & 0.218 & $0.060 * *$ \\
\hline Self-employed & & & 0.290 & $0.063 * *$ & 0.289 & $0.064 * *$ \\
\hline Civil servant & & & 0.064 & 0.063 & 0.065 & 0.065 \\
\hline White-collar worker & & & 0.162 & $0.038 * *$ & 0.168 & $0.039 * *$ \\
\hline \multicolumn{7}{|l|}{ Individual Data } \\
\hline German citizenship & & & -0.362 & $0.057 * *$ & -0.363 & $0.059 * *$ \\
\hline West German residency & & & 0.423 & $0.071 * *$ & 0.401 & $0.072 * *$ \\
\hline Married to foreign partner & & & & & 0.323 & $0.134 * *$ \\
\hline Married to German partner & & & & & -0.109 & $0.038 * *$ \\
\hline Children $\leq 3$ years & & & & & -0.087 & $0.043 * *$ \\
\hline Children 4-6 years & & & & & -0.099 & $0.046 * *$ \\
\hline \multicolumn{7}{|l|}{ Income } \\
\hline Net hourly wage (in DM) & & & & & 0.001 & $0.000 * *$ \\
\hline Retired & & & & & 0.144 & $0.086^{*}$ \\
\hline$\lambda_{1}:$ threshold for probit & -2.075 & 0.308 & -1.637 & 0.358 & -1.303 & 0.367 \\
\hline$\lambda_{2}:$ threshold for probit & -0.927 & 0.308 & -0.477 & 0.357 & -0.139 & 0.367 \\
\hline$\lambda_{3}:$ threshold for probit & 0.304 & 0.308 & 0.770 & 0.357 & 1.112 & 0.367 \\
\hline Pseudo $\mathrm{R}^{2}$ & 0.037 & & 0.045 & & 0.047 & \\
\hline Log-Likel. & -12578.9 & & -12474 & 521 & -1244 & 5.710 \\
\hline
\end{tabular}

Note: Results for the constant and the "year of survey" dummies are not reported. Reference categories are: Elementary school qualification for secondary and higher secondary school qualification, blue-collar worker for trainee, other, selfemployed, civil servant and white-collar worker, and not married for married to a foreign/German partner.

** and * indicate statistical significance at the 5 and 10 percent level respectively for the ordered probit estimation. 


\section{References}

Bashir, Ahmed and Gregory J. Robinson (1994): Estimates of emigration of the foreign-born population: 1980-1990, Population Division Working Paper No.9, Washington D.C.

Becker, Sascha O., Andrea Ichino and Giovanni Peri (2004): "How Large is the "Brain Drain" from Italy?" Giornale degli Economisti e Annali di Economia 63, 1-32.

Beggs, John J. and Bruce J. Chapman (1988): "Immigrant wage adjustment in Australia: cross section and time-series estimates", The Economic Record, 64 (186), 161-67.

Beggs, John J. and Bruce J. Chapman (1990): "Search efficiency, skill transferability and immigrant relative unemployment rate in Australia", Applied Economics, 22, 249-260.

Beggs, John J. and Bruce J. Chapman (1991): "Male Immigrant Wage and unemployment Experience in Australia", in: John M. Abowd and Richard B. Freeman: Immigration, Trade, and Labor Market, The University of Chicago Press: Chicago and London.

Borjas, George J. (1987): "Self-selection and the earnings of immigrants", The American Economic Review, 77, 531-533.

Borjas, George J. (1994): “The Economics of Immigration”, Journal of Economic Literature, 32, 1667-1717.

Borjas, George J. (1996): Labor economics, McGraw-Hill: New York....

Burda, Michael C., Wolfgang Härdle, Marlene Müller and Axel Werwatz (1998): "Semiparametric analysis of German east-west migration intentions: facts and history", Journal of Applied Econometrics, 13, 525-541.

Chiswick, Berry R. (1978): "The effect of Americanization on the earnings of foreign-born men”, Journal of Political Economy, 86, 897-921.

Chiswick, Berry R. and Paul W. Miller (1985): "Immigrant Generation and Income in Australia", The Economic Record, 61, 540-53.

Chiswick, Berry R. and Paul W. Miller (1995): "The endogeneity between language and earnings: international analyses", Journal of Labor Economics, 13, 246-288..

DaVanzo, Julie (1983): "Repeat migration in the United States: who moves back and who moves on?", Review of Economics and Statistics, 65, 552-559.

Dustmann, Christian (1993): "Earnings adjustments of temporary migrants", Journal of Population Economics, 6, 153-168.

Dustmann, Christian (1994): "Speaking fluency, writing fluency and earnings of immigrants", Journal of Population Economics, 7, 133-156.

Dustmann, Christian (1995): "Savings behavior of return migrants", Zeitschrift für Wirtschaftsund Sozialwissenschaften, 115, 511-533.

Dustmann, Christian (1996): "Return migration: the European experience", Economic Policy, 11, 215-250.

Dustmann, Christian (1997): "Return migration, uncertainty and precautionary savings", Journal of Development and Economics, 52, 295-316. 
EEAG (2003): Report on the European Economy 2003, European Economic Advisory Group at CESifo, Munich.

European Commission Directorate-General for Economic and Finance Affairs (1995): Performance of the European Union Labour Market, European Economy 3, Brussels.

Federal Statistical Office Germany (various volumes): Statistisches Jahrbuch für die Bundesrepublik Deutschland, Metzler und Poeschel: Wiesbaden.

Fernandez, Edward W. (1995): Estimation of the annual emigration of U.S. born persons by using foreign censuses and selected administrative data: circa 1980, Population Division Working Paper No.10, Washington D.C.

Greenwood, Michael J. and John M. McDowell (1991): "Differential Economic Opportunity. Transferability of Skills, and Immigration to the United States and Canada", The Review of Economics and Statistics, 73, 612-623.

Hamada, Koichi (1996): Strategic approaches to the international economy: Selected essays of Koichi Hamada, Elgar: Cheltenham.

Heckman, James J. (1979), "Sample Selection Bias as a Specification Error”, Econometrica, 47, 153-161.

Hicks, John R. (1932): The theory of wages, Macmillan: London.

Hunt, Jennifer (2000): Why do People still Live in East Germany, NBER Working Paper 7564, Cambridge, MA.

Iqbal, Mahmood (2000): "Brain Drain: Empirical Evidence of Emigration of Canadian Professionals to the United States", Canadian Tax Journal 48, 674-688.

Manski, Charles F. (1990): "The use of intentions data to predict behaviour: A best-case analysis", Journal of the American Statistical Association, 85, 934-940.

Mayer, Jochen and Regina Riphahn (2000): "Fertility assimilation of immigrants: evidence from count data models", Journal of Population Economics, 13, 241-61.

Mincer, Jacob (1978): “Family migration decision", Journal of Political Economy, 86, 749-773.

Münz, Reiner and Ralf Ulrich (1996): "Internationale Wanderungen von und nach Deutschland, 1945-1994”, Allgemeines Statistisches Archiv, 80, 5-35.

Naskoteen, Robert A. and Michael Zimmer (1980): "Migration and income: The question of selfselection", Southern Economic Journal, 46, 840-851.

Papapanagos, Harry and Peter Sanfey (2001): "Intention to emigrate in transition countries: the case of Albania", Journal of Population Economics 14, 491-504.

Schmidt, Christoph M. (1997): "Immigrant performance in Germany: labor earnings of ethnic German migrants and foreign guest-blue-collar workers", Quarterly Review of Economics and Finance, 37, 379-397.

Sjaastad, Larry A. (1962): "The costs and returns of human capital migration", Journal of Political Economy, Suppl. 70, 80-93.

Stark, Oded, Helmenstein Christian and Alexia Prskawetz (1997): “A brain gain with a brain drain", Economics Letters 55, 227-234. 


\section{CESifo Working Paper Series}

(for full list see www.cesifo-group.de)

1561 Carlo Altavilla and Paul De Grauwe, Non-Linearities in the Relation between the Exchange Rate and its Fundamentals, October 2005

1562 Josef Falkinger and Volker Grossmann, Distribution of Natural Resources, Entrepreneurship, and Economic Development: Growth Dynamics with Two Elites, October 2005

$1563 \mathrm{Yu}-\mathrm{Fu}$ Chen and Michael Funke, Product Market Competition, Investment and Employment-Abundant versus Job-Poor Growth: A Real Options Perspective, October 2005

1564 Kai A. Konrad and Dan Kovenock, Equilibrium and Efficiency in the Tug-of-War, October 2005

1565 Joerg Breitung and M. Hashem Pesaran, Unit Roots and Cointegration in Panels, October 2005

1566 Steven Brakman, Harry Garretsen and Marc Schramm, Putting New Economic Geography to the Test: Free-ness of Trade and Agglomeration in the EU Regions, October 2005

1567 Robert Haveman, Karen Holden, Barbara Wolfe and Andrei Romanov, Assessing the Maintenance of Savings Sufficiency Over the First Decade of Retirement, October 2005

1568 Hans Fehr and Christian Habermann, Risk Sharing and Efficiency Implications of Progressive Pension Arrangements, October 2005

1569 Jovan Žamac, Pension Design when Fertility Fluctuates: The Role of Capital Mobility and Education Financing, October 2005

1570 Piotr Wdowinski and Aneta Zglinska-Pietrzak, The Warsaw Stock Exchange Index WIG: Modelling and Forecasting, October 2005

1571 J. Ignacio Conde-Ruiz, Vincenzo Galasso and Paola Profeta, Early Retirement and Social Security: A Long Term Perspective, October 2005

1572 Johannes Binswanger, Risk Management of Pension Systems from the Perspective of Loss Aversion, October 2005

1573 Geir B. Asheim, Wolfgang Buchholz, John M. Hartwick, Tapan Mitra and Cees Withagen, Constant Savings Rates and Quasi-Arithmetic Population Growth under Exhaustible Resource Constraints, October 2005

1574 Christian Hagist, Norbert Klusen, Andreas Plate and Bernd Raffelhueschen, Social Health Insurance - the Major Driver of Unsustainable Fiscal Policy?, October 2005 
1575 Roland Hodler and Kurt Schmidheiny, How Fiscal Decentralization Flattens Progressive Taxes, October 2005

1576 George W. Evans, Seppo Honkapohja and Noah Williams, Generalized Stochastic Gradient Learning, October 2005

1577 Torben M. Andersen, Social Security and Longevity, October 2005

1578 Kai A. Konrad and Stergios Skaperdas, The Market for Protection and the Origin of the State, October 2005

1579 Jan K. Brueckner and Stuart S. Rosenthal, Gentrification and Neighborhood Housing Cycles: Will America's Future Downtowns be Rich?, October 2005

1580 Elke J. Jahn and Wolfgang Ochel, Contracting Out Temporary Help Services in Germany, November 2005

1581 Astri Muren and Sten Nyberg, Young Liberals and Old Conservatives - Inequality, Mobility and Redistribution, November 2005

1582 Volker Nitsch, State Visits and International Trade, November 2005

1583 Alessandra Casella, Thomas Palfrey and Raymond Riezman, Minorities and Storable Votes, November 2005

1584 Sascha O. Becker, Introducing Time-to-Educate in a Job Search Model, November 2005

1585 Christos Kotsogiannis and Robert Schwager, On the Incentives to Experiment in Federations, November 2005

1586 Søren Bo Nielsen, Pascalis Raimondos-Møller and Guttorm Schjelderup, Centralized vs. De-centralized Multinationals and Taxes, November 2005

1587 Jan-Egbert Sturm and Barry Williams, What Determines Differences in Foreign Bank Efficiency? Australian Evidence, November 2005

1588 Steven Brakman and Charles van Marrewijk, Transfers, Non-Traded Goods, and Unemployment: An Analysis of the Keynes - Ohlin Debate, November 2005

1589 Kazuo Ogawa, Elmer Sterken and Ichiro Tokutsu, Bank Control and the Number of Bank Relations of Japanese Firms, November 2005

1590 Bruno Parigi and Loriana Pelizzon, Diversification and Ownership Concentration, November 2005

1591 Claude Crampes, Carole Haritchabalet and Bruno Jullien, Advertising, Competition and Entry in Media Industries, November 2005

1592 Johannes Becker and Clemens Fuest, Optimal Tax Policy when Firms are Internationally Mobile, November 2005 
1593 Jim Malley, Apostolis Philippopoulos and Ulrich Woitek, Electoral Uncertainty, Fiscal Policy and Macroeconomic Fluctuations, November 2005

1594 Assar Lindbeck, Sustainable Social Spending, November 2005

1595 Hartmut Egger and Udo Kreickemeier, International Fragmentation: Boon or Bane for Domestic Employment?, November 2005

1596 Martin Werding, Survivor Benefits and the Gender Tax Gap in Public Pension Schemes: Observations from Germany, November 2005

1597 Petra Geraats, Transparency of Monetary Policy: Theory and Practice, November 2005

1598 Christian Dustman and Francesca Fabbri, Gender and Ethnicity - Married Immigrants in Britain, November 2005

1599 M. Hashem Pesaran and Martin Weale, Survey Expectations, November 2005

1600 Ansgar Belke, Frank Baumgaertner, Friedrich Schneider and Ralph Setzer, The Different Extent of Privatisation Proceeds in EU Countries: A Preliminary Explanation Using a Public Choice Approach, November 2005

1601 Jan K. Brueckner, Fiscal Federalism and Economic Growth, November 2005

1602 Steven Brakman, Harry Garretsen and Charles van Marrewijk, Cross-Border Mergers and Acquisitions: On Revealed Comparative Advantage and Merger Waves, November 2005

1603 Erkki Koskela and Rune Stenbacka, Product Market Competition, Profit Sharing and Equilibrium Unemployment, November 2005

1604 Lutz Hendricks, How Important is Discount Rate Heterogeneity for Wealth Inequality?, November 2005

1605 Kathleen M. Day and Stanley L. Winer, Policy-induced Internal Migration: An Empirical Investigation of the Canadian Case, November 2005

1606 Paul De Grauwe and Cláudia Costa Storti, Is Monetary Policy in the Eurozone less Effective than in the US?, November 2005

1607 Per Engström and Bertil Holmlund, Worker Absenteeism in Search Equilibrium, November 2005

1608 Daniele Checchi and Cecilia García-Peñalosa, Labour Market Institutions and the Personal Distribution of Income in the OECD, November 2005

1609 Kai A. Konrad and Wolfgang Leininger, The Generalized Stackelberg Equilibrium of the All-Pay Auction with Complete Information, November 2005 
1610 Monika Buetler and Federica Teppa, Should you Take a Lump-Sum or Annuitize? Results from Swiss Pension Funds, November 2005

1611 Alexander W. Cappelen, Astri D. Hole, Erik Ø. Sørensen and Bertil Tungodden, The Pluralism of Fairness Ideals: An Experimental Approach, December 2005

1612 Jack Mintz and Alfons J. Weichenrieder, Taxation and the Financial Structure of German Outbound FDI, December 2005

1613 Rosanne Altshuler and Harry Grubert, The Three Parties in the Race to the Bottom: Host Governments, Home Governments and Multinational Companies, December 2005

1614 Chi-Yung (Eric) Ng and John Whalley, Visas and Work Permits: Possible Global Negotiating Initiatives, December 2005

1615 Jon H. Fiva, New Evidence on Fiscal Decentralization and the Size of Government, December 2005

1616 Andzelika Lorentowicz, Dalia Marin and Alexander Raubold, Is Human Capital Losing from Outsourcing? Evidence for Austria and Poland, December 2005

1617 Aleksander Berentsen, Gabriele Camera and Christopher Waller, Money, Credit and Banking, December 2005

1618 Egil Matsen, Tommy Sveen and Ragnar Torvik, Savers, Spenders and Fiscal Policy in a Small Open Economy, December 2005

1619 Laszlo Goerke and Markus Pannenberg, Severance Pay and the Shadow of the Law: Evidence for West Germany, December 2005

1620 Michael Hoel, Concerns for Equity and the Optimal Co-Payments for Publicly Provided Health Care, December 2005

1621 Edward Castronova, On the Research Value of Large Games: Natural Experiments in Norrath and Camelot, December 2005

1622 Annette Alstadsæter, Ann-Sofie Kolm and Birthe Larsen, Tax Effects, Search Unemployment, and the Choice of Educational Type, December 2005

1623 Vesa Kanniainen, Seppo Kari and Jouko Ylä-Liedenpohja, Nordic Dual Income Taxation of Entrepreneurs, December 2005

1624 Lars-Erik Borge and Linn Renée Naper, Efficiency Potential and Efficiency Variation in Norwegian Lower Secondary Schools, December 2005

1625 Sam Bucovetsky and Andreas Haufler, Tax Competition when Firms Choose their Organizational Form: Should Tax Loopholes for Multinationals be Closed?, December 2005

1626 Silke Uebelmesser, To go or not to go: Emigration from Germany, December 2005 